\title{
Education and training in Brazilian botanical gardens: are we achieving GSPC targets?
}

\author{
Tania Maria Cerati ${ }^{{ }^{*}}$
}

\begin{abstract}
Engage, educate and raise public awareness of the importance of plant diversity is the means through which plant conservation can be achieved. The Global Strategy for Plant Conservation (GSPC) is a programme to halt the loss of plant diversity and recognize botanical gardens as a partners. This paper investigates the implementation of targets 14 and 15 GSPC in Brazilian botanic gardens specially in education and awareness about plant diversity and trained people. A survey was carried out on the institutional websites of 21 gardens registered in the National System of Botanical Gardens Registration to identify actions that follow the guidelines of these two targets. Websites outdated, difficult access and lack online resources for the public shows us that internet tools are poorly used to divulgation. The target 14's activities performed in most gardens are educational visits and environmental interpretation and explore collections in situ and ex situ from representative species of regional flora. Trained people is held in all gardens but some stand out as important research centers and graduate programs. Despite the efforts Brazilian botanical gardens need improve the public communication and develop strategies to measure the targets progress.
\end{abstract}

Key words: botanical gardens, education, GSPC.

\section{Resumo}

Engajar educar e aumentar a consciência das pessoas da necessidade da conservação das plantas é o meio pelo qual a conservação de plantas pode ser alcançada. A Estratégia Global para Conservação de Plantas (GSPC) é um programa para deter a perda contínua de diversidade de plantas e reconhece os jardins botânicos como parceiros. Este estudo investiga a implantação das Metas 14 e 15 da GSPC relacionadas a educação e conscientizaçãosobre a diversidade de plantas e capacitação. Foi realizado um levantamento nos websites de vinte e um jardins botânicos brasileiros cadastrados no Sistema Nacional de Registros de Jardins Botânicos para identificar as ações que seguem as orientações dessas duas metas. Websites são desatualizados, difícil navegação e falta recursos on-line para o público mostram que as ferramentas de internet são pouco utilizadas para a divulgação. As ações da meta 14, realizadas na maioria dos jardins, são visitas educativas e interpretação ambiental que exploram as coleções in-situ e ex-situ com espécies representativas da flora regional. A capacitação de equipes é realizada em todos os jardins, sendo que alguns se destacam como importantes centros de pesquisa e programas de pós-graduação. Apesar dos esforços, os jardins botânicos brasileiros precisam melhorar a comunicação pública e criar indicadores para avaliar o progresso da implantação das metas.

Palavras-chave: jardins botânicos, educação, GSPC.

\section{Introduction}

Concepts of targets 14 and 15

of the Global Conservation Strategy

of Plants (GCSP)

Implications concerning the environmental crisis on biodiversity loss came under discussion during the half of the $20^{\text {th }}$ century. Within this context, botanical gardens are important for the biodiversity conservation policies, especially the creation of targets for the Global Strategy for Plant Conservation - GSPC.

The GSPC provides a framework for working together at all levels (local, national, regional and global) to understand, conserve and use sustainably the world's immense wealth of plant diversity

\footnotetext{
${ }^{1}$ Instituto de Botânica, Secretaria de Estado do Meio Ambiente, Núcleo de Pesquisa em Educação para Conservação, Av. Miguel Stéfano 3687, Água Funda, 04301-902, São Paulo, SP,

* Author for correspondence: taniacerati@gmail.com
} 
whilst promoting awareness of the importance of plants and their conservation needs.

The choice of botanical gardens to establish conservation policies is due to their undeniable importance as providers of knowledge for formal education in key areas of biodiversity research, as well as to contribute to the development and establishment of new botanical gardens (Blackmore et al. 2011). Knowledge contained in botanical gardens provides a great many solutions for environmental problems (Crane et al. 2009) as well as for species extinctions (Willison et al. 2006). However, the challenge today is to communicate the public with a broader understanding about plants conservation, targeting not only education but also needed support for research and training in these gardens. Public undervalued plants leads to scarce public knowledge about biodiversity and the importance of conservation (Lindemann-Matthies $\&$ Bose 2008). Not recognize plants and their importance to biosphere, leads us to conclude that plants are inferior and less important than animals Wandersee \& Schussler (2001).

Therefore, education and training are essential elements for these institutions play an important role in formal and informal education (Rennie \& Williams 2002; Braund \& Reiss 2006), however studies on education in botanical gardens are few (Sellmann \& Bogner 2013).

Educational activities in botanical gardens are directed especially to students, an important part of the total number of visitors (Kneebone \& Willison 2007). This is a positive factor it means that children are in contact with nature, encouraging biophilia and creating new attitudes to environment protection.

According to Willison et al. (2006), conservation projects will not succeed without investing in education for the people involved. We should remember that $50 \%$ of the world's population lives in urban areas ${ }^{1}$ and therefore we must create strategies to involve the local people in the preservation of natural heritage. Botanical gardens have a unique potential to contribute to the education process mainly of those who live in urban centers, sharing knowledge and providing direct contact with plants.

Research in Brazil (Brasil 2015) has shown that people in general view botanical gardens and zoos as scientific places, where topics related to

\footnotetext{
In Brazil this his number reaches $80 \%$ according to IBGE - Instituto Brasileiro de Geografia e Estatística.
}

environment, especially those related to climate change, habitat loss and biodiversity loss, arouse interest. These factors stimulate people to visit botanical gardens, zoos and parks that provide their visitors with scientific knowledge on the environment (FAPESP 2010).

It is interesting to note that in spite of recognizing the importance of education, $26 \%$ of botanical gardens worldwide do not have a budget for education (Kneebone \& Willison 2007). This is a recurrent fact and although botanical gardens understand the importance of education this subject still holds lower priority in many botanical gardens. However, creation of the targets of GSPC plus financial resources by $\mathrm{BGCI}$, has led to increased understanding among botanical garden professionals as regards how targets should be focused (Blackmore et al. 2011).

Target 14 created a collective effort to inform the public of the importance of biodiversity and the urgent need for conservation. Thus botanical gardens create their educational team giving rise to an education areas (Gaio-Oliveira et al. 2017; Kneebone \& Willison 2007).

Some analyses were carried out concerning the installation of the first phase of GSPC (20002010) in botanical gardens worldwide. According to Williams et al. (2012), the first phase showed us the older botanical gardens with their budgets were more able to establish Strategies. Target 14 was more likely to be adopted, since it increases the visibility of the botanical garden. However, the study showed that a lack of personnel and financial resources, as well as of communication between managers and knowledge sharing were actually bottlenecks to installation. Botanical gardens are potentially able to fit within the aims of GSPC, but most of them establish 5 or 6 targets with education always being included (Blackmore et al. 2011).

Here we aim to diagnose educational activities carried out in Brazil's botanical gardens and to search for evidence that may or may not contribute to targets 14 and 15 of the Global Strategy for Plant Conservation (GSPC). Target 14 aims to promote education and awareness of biodiversity as well as the means for a sustainable life as well as its importance for the planet. This objective is to approach the importance of plant diversity and the need for its conservation incorporated into communication, education and public awareness programmes.the importance of species diversity as well as the need for biodiversity conservation in programs geared towards communication, 
education and public awareness. Target 15 aims trained people working with appropriate facilities sufficient according to national needs, to achieve the targets of this Strategy.

The first stage of GSPC (2000-2010) in Brazil: instrument of orientation for creation of educational programs in the botanical gardens

An important example of activities aimed at the development of GSPC targets (2000-2010) was the "Investing in Nature" program. Here, botanical gardens are seen as prime centers of education concerning plants and their importance for the millions that visit the botanical garden every year. Based on this view, BGCI (Botanic Gardens Conservation International) provided financial resources and selected conservation projects for endangered species, education and public awareness programs in botanical gardens of Argentina, Brazil, Canada, China, India, Indonesia, Jordan, Mexico, Russia and USA (Wyse-Jackson \& Kennedy 2009). Efforts by BGCI to establish the first phase of GSPC recognized by the botanical gardens in Brazil. Activities related to education and training are given below.

During this period, the Brazilian Network of Botanical Gardens (RBJB) aggregated botanical gardens to reduce biodiversity loss. A action plan was set up to guide works documenting the flora to include conservation, environmental education and sustainable, taking into consideration important social and economic differences that are found in a country the size as Brazil (Pereira et al. 2004). The action plan consisted of five activity spheres, including "Education to conserve plant biodiversity" where the following targets should be contemplated: 1 . create institutional environmental education teams; 2 . teach the general public to conserve biodiversity; 3 . guarantee that botanicalgarden importance for the cause of conservation be recognized by people in general, by government and private sector (Pereira et al. 2004).

Based on financial support by the "Investing in Nature" Program and partnership between RBJB and BGCI an Action Plan was drawn up and installed. From this point on, Brazilian botanical gardens to search for ways to overcome difficulties and promote advance in activities directed towards public awareness on the importance of biodiversity conservation (Pereira \& Costa 2010). The project "O jardim botânico vai à escola" created by Brazilian Network of Botanical Gardens is a prime exemple of a project carried out nationwide. The aim was to establish an educational project with a school community in order to: socialize the knowledge created in the botanical gardens; engage the local population in activities of the botanic garden; consolidate educational programs. Adoption of methods and pedagogical material enriched by material on regional biodiversity, permitted the approximation of gardens to the culture of each region. Carried out from 2006 to 2011 it included 22 gardens, 72 schools, for a total of 1,726 teachers and 26,800 participating students (Cerati 2011). Many challenges were overcome such as: bring together the educational activities of the gardens in a country of continental size; include references of regional culture and optimizar the effort to reduce staff of botanical gardens. This effort shows that networking is basic to foment capacitation of workers and implantation of broadscale projects.

After this period, several botanical gardens continued actions with support from local and state governments and universities. In Brazil, the first stage of GSPC provided structure for developing activities that would be applied to Target 14 and 15 , promoted changes in communication between gardens and consolidated the environmental education in Brazilian botanical gardens.

Why work with targets?

In 2002 the United Nations Convention on Biological Diversity (CBD) adopted the Global Strategy for Plant Conservation (GSPC), with long-term objectives to curb the ongoing loss of global biodiversity, including 16 targets targeting innovative activities at local, national and global levels to 2010 (Sharrock et al. 2014; Wyse-Jackson \& Kennedy 2009). The simple formula, clear layout and 16 targets were accepted by all involved in plant conservation and widely adopted as a focus of action (Rae 2003). In 2008, the CBD agreed to consider the further development of the GSPC after 2010 and called for proposals for a 'consolidated update' of the Strategy. Continuing the multidisciplinary nature of conservation activities and the need for scientific, social, economic integration and problem solving to achieve the targets (Wyse-Jackson \& Kennedy 2009).

The botanical gardens responded positively to GSPC because it provided guidelines for basic actions allied to the commitment to change priorities and redistribute existing resources (Blackmore et al. 2011). Despite the success achieved, GSPC 
suggests that the difficulty of obtaining effective progress in the conservation of plants is especially linked to botanical blindness and the inadequacy of resource allocation. It is necessary for governments to assume an effective commitment to make use of technical knowledge available for conservation at national and international level.

In Brazil the GSPC stimulated the realization of various studies in different areas of education. The educational role where teachers and students are involved is stressed by Silva et al. (2009), Araujo et al. (2013) and Cerati \& Lazarini (2009), who studied the dissemination of scientific knowledge and reflected on the importance of regional biodiversity preservation. Aware of the fact that botanical gardens are relevant to informal education, Rodrigues (2017) and Cerati (2014) studied the potential of educational activity in promoting scientific literacy. They pointed out that the materials produced and exhibited by these institutions contribute to the understanding of scientific topics. Cerati \& Souza (2016) report a learning experience for the community surrounding a botanical garden to make people aware of the importance of maintaining "in situ" vegetation to minimize man's activities and improve the region's environmental quality, thus reinforcing the fact that education of the population around protected areas is a strong ally for the conservation of biodiversity. These studies are encouraging, since only $1 / 3$ of the world's botanical gardens do research in the area of education (Kneebone \& Willison 2007) and lead us to reflect on the impact of education in botanical gardens as regards the various groups of people attending and encourages more effective education (Willison et al. 2006).

In spite of surveys cited in Brazil there are no data available on educational activities in botanical gardens, nor can we determine if we are contributing or not to GSPC. So the question is: that education offers the brazilian botanical gardens to the public?

\section{Methodology}

In order to determine how Brazilian Botanical Gardens contribute to GSPC, this study does a diagnosis of educational activities in order to understand how they contribute to targets 14 and 15 of GSPC 2011-2020. A survey was carried out on the institutional websites of 21 Botanical Gardens registered in the "National System of Botanical Gardens Registration" (Tab. 1) in October 2017. Educational activities available to the public and reported at the website were identified. These activities were classified according to the aims of GSPC targets 14 and 15 . As we see it, the institutional website is an online business card and a channel of communication with the public, after the garden itself and should therefore reveal all activities intended for communication with and education of the public.

\section{Results}

The botanical gardens that constitute this study are located in 12 states of Brazil, especially in the southeastern region, with the highest number being in São Paulo. We see that twelve gardens have their own websites with information on educational activities, research and conservation. At five institutions, information can be found at government websites; for two gardens information is presented as news on the government website along with that of other secretariats; one garden does not have a website (Jardim Botânico Amália Hermano Teixeira de Goiânia) and there is no

Table 1 - Botanical gardens present in the National System of Botanical Gardens Registration and survey participants

Rio de Janeiro Botanical Garden (JBRJ)
Botanical Garden of the Zoobotanic Foundation Rio Grande
do Sul (JBRGS)
Brasília Botanical Garden (JBB)
São Paulo Botanical Garden (JBSP)
Recife Botanical Garden (JBR)
Amália Hermano Teixeira Botanical Garden (JBAHT)
Botanical Garden of Zoobotanic Foundation Belo Horizonte
$\quad$ (JBBH)
Inhotim Botanical Garden (JBI)
Jundiaí Botanical Garden (JBJ)
Botanical Garden of Campinas Agronomic Institute (JB IAC)
Municipal Botanical Garden of Bauru (JBBauru)
Poços de Caldas Botanical Garden (JBPC)
Botanical Garden of Federal Rural University of Rio de
$\quad$ Janeiro (JB UFRJ)
Salvador Botanical Garden (JBS)
Municipal Botanical Garden of Santos (JBMS)
Municipal Botanical Garden os São José (JBMSJ)
Municipal Botanical Garden of Curitiba (JBCuritiba)
Plantarum Botanical Garden (JBP)
National Institute of the Atlantic Forest (INMA) - antigo
$\quad$ Museu de Biologia Mello Leitão
Natural History Museum and Botanical Garden of UFMG (JB
UFMG)
Emílio Goeldi Museum of Pará (JB MPEG)


information available on its activities at the government website; one garden website has not been updated since 2012 (Jardim Botânico de Salvador). So, the institutional websites are very poorly utilized as well as other internet tools and the educators are throwing away a very important feature of interpretation and disclosure. However, there are bureaucratic problems in updating and altering the content of websites, especially those linked to government. The literature points out that shortages in online resources are common and gardens in North America and Oceania are the ones that use this resource extensively (GaioOliveira et al. 2017).

Eleven activities were identified to that meet target 14 (Tab. 2), four being directed towards qualification that is the focus of target 15 .

As regards Target 14, educational visits are held in 19 gardens and usually explore collections in situ and ex situ where species are representative of regional plant formations near the garden. Visits to living collections is favorable to interaction of society with the garden, resulting in various strategies of communication and awareness that provide the visitor with a better concept of biodiversity (Gouveia et al 2007). This is also a more effective way to achieve target 14 (Sharrock et al. 2014). These visits usually accompanied by a monitor and contribute to a better understanding of biodiversity, environmental awareness and making interactive science more popular, plus stimulating contact and experiences for the visitor. We see that visits are directed to various groups, but especially to schools, as also observed by Gaio-Oliveira et al. (2017) and Kneebone \& Willison (2007), in the gardens around the world. It should be noted that the monitors who do educational visits are generally young, with low wages and high turnover, but are essential to establish dialogue between garden and public (Bailey 2006). So to maintain visits, the gardens must have a budget for this purpose and an ongoing program to train monitors by the education team.

Nine gardens produce educational material to inform visitors. This material may be available on the website as itineraries, handouts or didactic activities. The gardens also support students and teachers with a library and videos as a complement to educational visits, thus reinforcing didactics and the view that education in botanical gardens is an instrument of support to complement formal education.
Environmental interpretation is present in ten gardens and includes maps, guides, folders and plates of different types. Interpretation is a characteristic of botanical gardens (Gaio-Oliveira et al. 2017), so we believe that all the gardens participate in the interpretation of nature, but do not show this on the website. Some gardens have a virtual tour website and interpretative photos. Examples such as Kew Gardens and Fairchild Tropical Botanic Garden, respectively, in the UK and USA. Websites show many pictures of public interaction with the interpretative apparatus, an advertising technique and stimulus for face-to-face visits, which should be exploited to a greater extent by Brazilian gardens.

Biodiversity-related exhibitions are part of the activities of many gardens. Cultural events include presentation of orchestras, choirs and small musical groups, always present in various cultural events held by the gardens.

Four gardens (JB Bauru, JB Inhotim, JB Poços de Caldas and JB UFMG) as having interactive-educational activities that, according to website description, stimulate contact peoplenature and encourage learning by interaction with species preserved in the garden. New ways of attracting the child-juvenile public at times when they are out of school are being added to activities of the gardens, such as: Science in the Square (JBRGS), Summer camp (JB UFMG), Holidays in the Garden (JB Plantarum) this providing countless opportunities to bring together education and leisure. The educational workshops are also present under different themes.

We found that two gardens have applications available to the public. Jardim Botânico Plantarum, of the Plantum Institute, has material applicable to setting up residential gardens and others for plant identification. Jardim Botânico de Recife has developed a guide for a trail of endangered plants. This innovation, as compared to the lack of use of digital tools discussed above, shows an interest in the use of these tools to expand educational activities and several botanic gardens are investing in this.

The targets of environmental education described in some websites were widely discussed among Brazilian gardens for the GSPC implementation (2000-2010) therefore they are consolidated and orientating education.

To implement activities that aim to achieve GSPC Targets, botanical gardens need teams technically trained in different areas, with facilities 


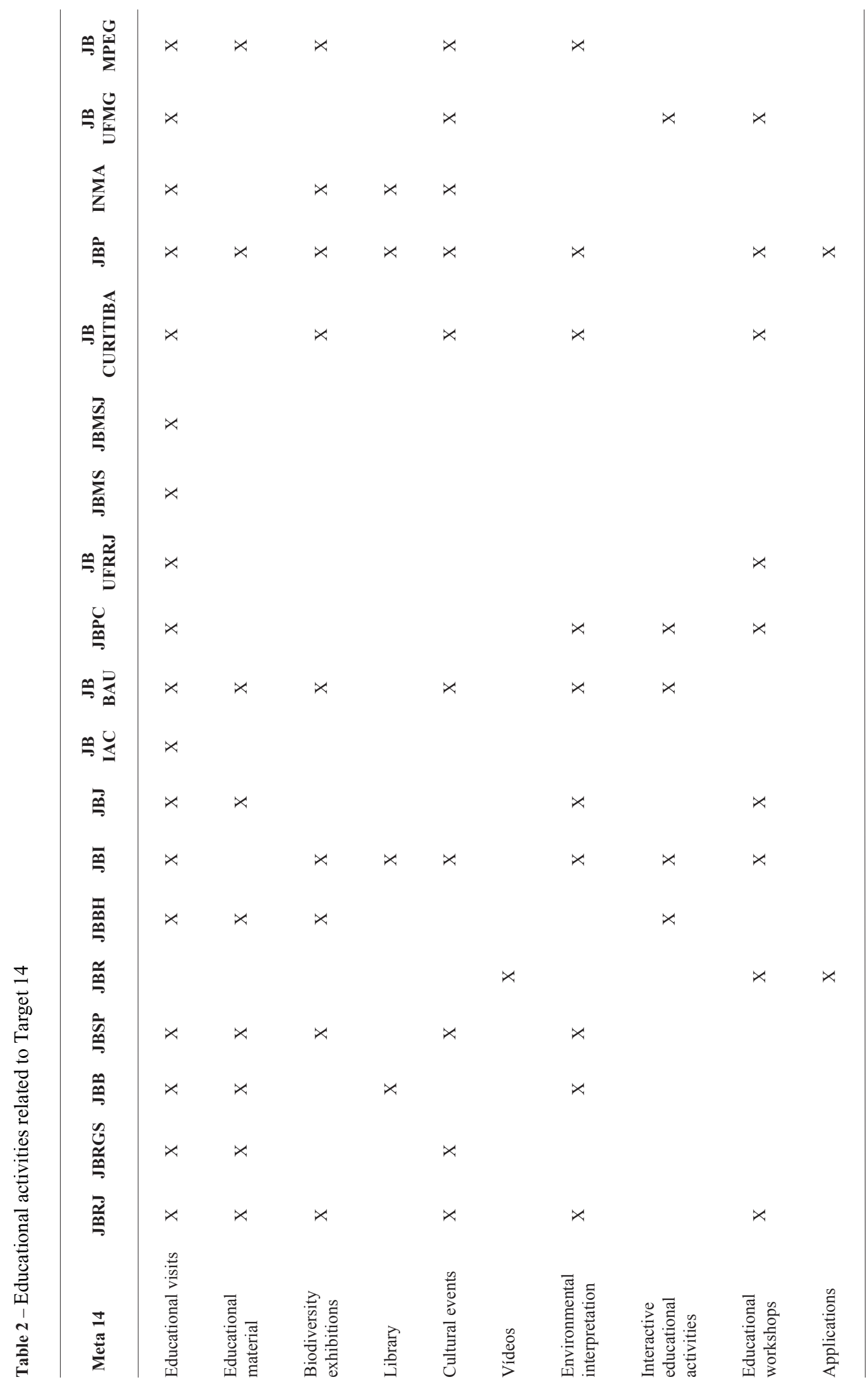


and equipment suitable for this. Team training is the aim of Target 15 and what is needed achieve this can be found in Table 3 .

We saw that thirteen gardens have a professional training course that involves two public categories: educators and training of gardeners. In JBRGS the educator training course has both practical and theoretical content, addressing the concept of a botanical garden and the importance of collections for biodiversity conservation. By broadening teachers' knowledge about the garden and collections, they are encouraged to make visits that favor engagement and interactivity of students with biodiversity and local reality. Courses for training gardeners contemplate vocational training of low-income people and are carried out at JBRJ and JBSP, thus revealing responsibility and social inclusion in education.

The importance of botanical gardens as providers of formal education (Blackmore et al. 2011) translates into the maintenance of graduate programs (both MS and $\mathrm{PhD}$ ), especially in older botanical gardens such as JBRJ, JBSP, JB IAC and JBMPEG as well as those linked to universities such as JB UFRRJ and JB UFMG. Inclusion of graduate programs in botanical gardens was a way of meeting development demands, with the expansion of scientific and academic programs all over Brazil. A high-quality graduate program requires complex infrastructure (often at high cost), a fair number of high-level, productive researchers and a consolidated research environment, factors already present in older gardens. Scientific initiation programs are also carried out in several gardens (Tab. 3).

So Target 15 is attained by the gardens and training occurs at various levels, with different objectives. The attainment of this target (in one form or another) depends on variables such as garden history, training of technical staff and institutional policies.

\section{Initiatives in other countries}

Different ways of engaging the public are being done in botanical gardens in various parts of the world. Gardens open opportunities to include the public in citizen science projects, focused in data collection of rare or endangered species, phenology monitoring, invasive species and reintroduction and restoration (Donaldson 2009). As an example, two initiatives where the public is the data collector: Projetos Plants of Concern do Chicago Botanic Garden, where rare and endangered species are monitored; and BudBurst project carried out in partnership with several american gardens that monitor species budding in the spring throughout the country. The contribution of the population to science is also highlighted in the Protea project Atlas of South Africa. Accomplished over the course of ten years the scientific data are used for the conservation of species populations of the Proteaceae family.

These projects contribute to the understanding of relationships between species that share the ecosystem, impacts of human action on the biota and importance of conservation, factors that favor greater understanding of environmental problems by the population.

The "Fascination of Plants Day" is coordinated by the European Plant Science Organisation (EPSO) and aims to involve the public of different countries to recognize the importance of plants for agriculture and sustainable production of food, horticulture, forestry and the production of non-food goods, such as paper, wood, chemicals, pharmaceuticals and energy (Sharrock et al. 2014). Many scientific institutions, universities, schools, botanical gardens and museums open their doors to raise public awareness. In Brazil only one institution participates in this event and it is not a botanical garden.

Innsbruck Botanic Garden, in Austria, coordinates the Plant Science Gardens project, aiming to improve botanical education in schools through partnership with botanical gardens, primary schools and national school boards. Currently, there are 4 countries, with 112 teachers and 60 primary schools involved in the project. The results include activities in the botanical garden, teacher training in conservation and sustainability issues of species, food, plants in art and daily life and ecology.

These are large projects that reach a great number of people and are carried out in partnership between gardens, community and with different socially oriented groups. The partnership should be encouraged in Brazil as a way to strengthen the educational role of botanical gardens.

\section{Policies to achieve the targets}

Today there are over 20 global conservation treaties, each with its own set of policies intended to influence decisions and stimulate change to contain threats and impacts on biodiversity, however lack assessment of the impact of international politics especially in the South American countries (Williams et al. 2012). 


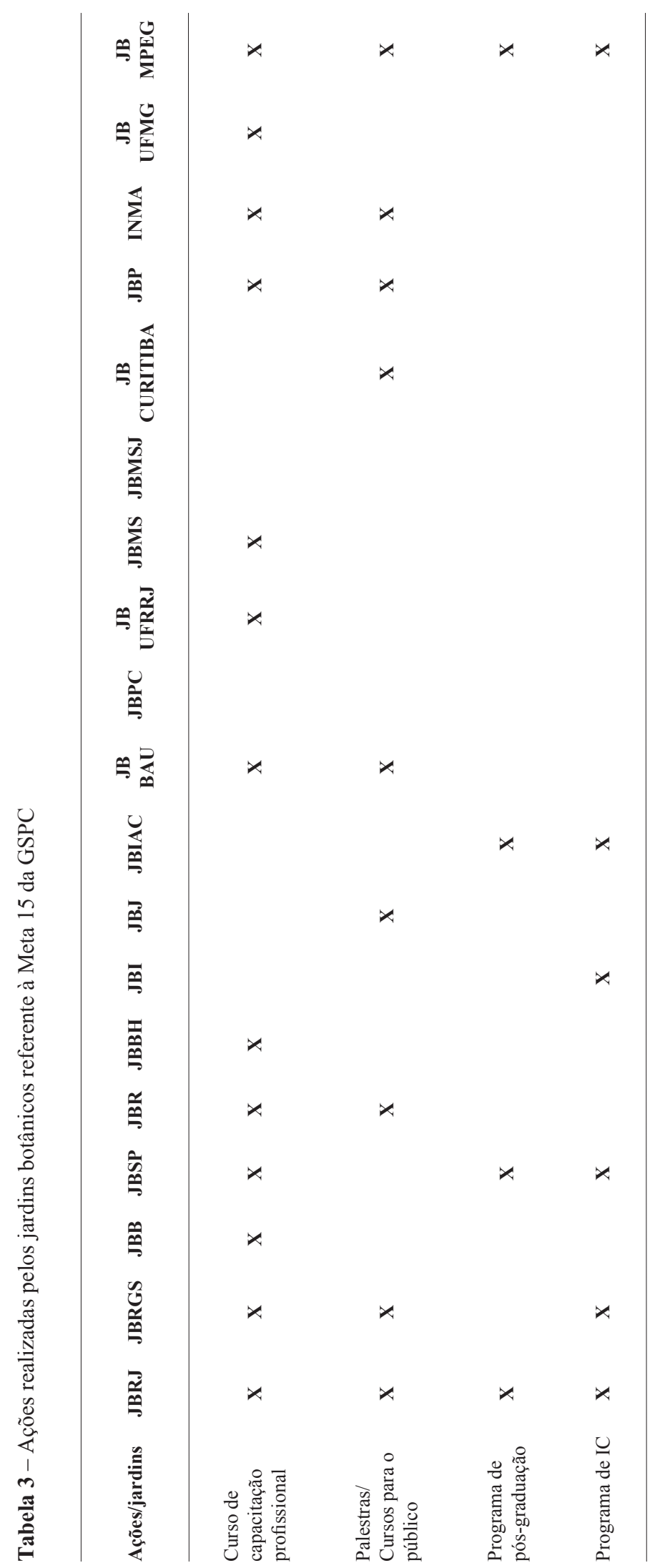


An evaluation of the first phase of GSPC in botanical gardens of 67 countries shows that some $80 \%$ of the gardens had their activities modified and/or implemented based on the influence of GSPC, with focus intensely on Target 14 (Williams et al. 2012). This result also applies to Brazil. The first phase of GSPC 2000-2010 was a new guidelines for Brazilian gardens, once through the program "Investing in Nature" teams and decision makers were mobilized to implement targets, producing significant comprehensive results. The financial contribution was decisive for this successful result.

The importance of establishing partnerships between botanical gardens and government aimed to develop educational projects that stimulate changes of habits and formation responsible of citizens is reported by Cerati and Tibério (2016). This strategy sensitizes managers concerning the potential of Brazilian botanical gardens as entities for communication and public education.

Recomendation for post 2020 targets

In order to create a discussion concerning what directions can we take after 2020 to reach the objectives of GSPC, we suggest some activities for strengthening education and training in botanical gardens.

There is no indicator to quantify the education and public awareness programmes and the number of people involved. Develop strategies to measure the targets progress.

Actions involving managers, community, excluded groups, entrepreneurs from tourism, urban planners and natural areas, aiming at new ways to capture resources, offer new services, establis partnerships and increase institutional visibility.

Increase interaction between gardens. Create an online interactive forum for exchange of information, knowledge, project drafting, fundraising, etc. In this way original solutions could be found for cronic problems.

Improve the public communication using internet tools, especially modernization and updating of websites with more content available. Seen as an online business card, the website allows dissemination of the garden around the world, stimulates visitation, advertises the garden and provides an evaluation mechanism for measuring the amount of accesses.

Invest in voluntary programs to promote educational activities.
Strengthen interaction with BGCI, use the materials available online to help implement the targets 14 and 15 .

This brief study shows that gardens played an important role in the first phase of the GSPC (2000-2010) because they worked online, received financial help and the teams were trained. Results were successful. In the second phase (2011-2020) there was disarticulation of the gardens that carried on working in isolation, but the objectives of the educational activities are in line with GSPC. There are difficulties imposed on Brazilian botanical gardens, especially when faced with a grave political and financial crisis. Trained teams are reduced and maintenance of training programs is compromised. But the teams continue to mobilize efforts to broaden public awareness on the importance of biodiversity conservation.

\section{Acknowledgments}

We would like to thank the Dra. Dorothy Sue Dunn de Araujo for translate to English the manuscript.

\section{References}

Araújo JN, Silva CC, Dias O, Terán AF \& Gil AX (2013) Jardim Botânico Adolpho Ducke: uma possibilidade para a educação científica na Amazônia. Novas Perspectivas de Ensino de ciências em espaços não formais amazônicos. UEA, Manaus. Pp. 187-197.

Bailey EB (2006) Researching museum educators' perceptions of their roles, identity, and practice. Journal of Museum Education 31: 175-197.

Blackmore S, Gibby M \& Rae D (2011) Strengthening the scientific contribution of botanic gardens to the second phase of the Global Strategy for Plant Conservation. Botanical Journal of the Linnean Society 166: 267-281.

Brasil (2015) Ministério da Ciência, Tecnologia e Inovação/Museu da Vida. Percepção pública da ciência e tecnologia no Brasil 2015: a ciência no olhar dos brasileiros. Available at $<$ http:// percepcaocti.cgee.org.br/>. Access on 7 March 2017.

Braund M \& Reiss, M (2006) Toward a more authentic science curriculum: the contribution of out-of-school learning. International Journal of Science Education, 28: 1373-1388.

Cerati TM \& Lazarini, RAM (2009) A pesquisa-ação em educação ambiental: uma experiência no entorno de uma unidade de conservação urbana. Ciência \& Educação 15: 2.

Cerati TM (2011) O jardim botânico vai à escola: a experiência dos jardins botânicos. Secretaria do Meio Ambiente do Estado de São Paulo, São Paulo. 155p. 
Cerati TM (2014) Educação em jardins botânicos na perspectiva de alfabetização científica: análise de uma exposição e público. Tese de Doutorado. Universidade de São Paulo, São Paulo. 213p.

Cerati TM \& Souza AQ (2016) Participación social en la gestión ambiental: estudio de caso en una unidad de conservación urbana en el municipio de São Paulo, Brasil. Estudios Demográficos y Urbanos 31: 87-113.

Cerati TM \& Tibério CK (2016) Brinquedo sucata: uma estratégia para repensar o consumo. Revista Eletrônica do Mestrado em Educação Ambiental 33 (especial): 85-101. Available at $<$ https://www.seer. furg.br/remea/article/view/5334/4348>. Access on December 2017.

Crane PR, Hopper SD, Raven PH \& Stevenson DW (2009) Plant science research in botanic gardens. Trends in plant Science 14: 575-577.

Donaldson JS (2009). Botanic gardens science for conservation and global change. Trends in plant Science 14: 608-613.

FAPESP (2010) Indicadores de Ciência, Tecnologia e Inovação em São Paulo. Available at $<\mathrm{http}$ ://www. fapesp.br/indicadores/2010/volume2/cap12.pdf >. Access on July 2017.

Gaio-Oliveira G, Delicado A \& Martins-Loução MA (2017) Botanic gardens as communicators of plant diversity and conservation. The Botanical Review 83: 282-302.

Gouveia MTJ, Saísse MV, Wenzel MSMT, Bottino CS \& Rueda MMM (2007) A mediação de visitas no Jardim Botânico do Rio de Janeiro. In: Massarani L (org.) Diálogos \& ciência: mediação em museus e centros de ciências. Museu da Vida, Rio de Janeiro. Pp. 81-87.

Lindemann-Matthies P \& Bose E (2008) How many species are there? Public understanding and awareness of biodiversity in Switzerland. Human ecology 36: 731-742.

Kneebone S \& Willison J (2007) A global snapshot of botanic garden education provision. In: Building a sustainable future: the role of botanic gardens. Proceedings of the $3^{\text {rd }}$ Global Botanic Gardens Congress, Wuhan, China. Pp. 1-14.

Pereira TS, Costa MLN, Wyse-Jackson P (2004) Plano de ação para os jardins botânicos brasileiros. Rede Brasileira de Jardins Botânicos (orgs). Plano de ação para os jardins botânicos brasileiros. Rede Brasileira de Jardins Botânicos, Rio de Janeiro. 44p. il.
Pereira TS \& Costa MLN (2010) Os jardins botânicos brasileiros: desafios e potencialidades. Ciência e Cultura 62: 23-25.

Rae D (2003) An introduction to the global strategy for plant conservation. Sibbaldia 1: 25-28.

Rennie LJ \& Williams GF (2002) Science centers and scientific literacy: promoting a relationship with science. Science Education 86: 706-726.

Rodrigues, J (2017) Estudando a alfabetização científica por meio de visita roteirizada a uma exposição de jardim botânico. Dissertação de Mestrado. Universidade de São Paulo, São Paulo. 176p.

Sellmann D \& Bogner FX (2013) Climate change education: quantitatively assessing the impact of a botanical garden as an informal learning environment. Environmental Education Research 19: 415-429.

Silva FL, Rodrigues PFM, Talamoni JLB, Ruiz SS, Andreo M, Fragoso SB, \& Bochini, GL (2009) Bioindicadores da qualidade da água: subsídios para um projeto de educação ambiental no Jardim Botânico Municipal de Bauru, SP. Revista Ciência em Extensão: 94-105.

Sharrock S, Oldfield, S \& Wilson O (2014) Plant Conservation Report 2014: a review of progress in implementation of the Global Strategy for Plant Conservation 2011-2020. CBD Technical Series 81. Secretariat of the Convention on Biological Diversity, Montreal, and Botanic Gardens Conservation International, Richmond. 56p.

Wandersee J \& Schussler E (2001) Toward a theory of plant blindness. Plant Science Bulletin 47: 2-9.

Williams SJ, Jones JP, Clubbe C, Sharrock S \& Gibbons JM (2012) Why are some biodiversity policies implemented and others ignored? Lessons from the uptake of the Global Strategy for Plant Conservation by botanic gardens. Biodiversity and Conservation 21: 175-187.

Willison J (2003) Educação ambiental em Jardins Botânicos: diretrizes para o desenvolvimento de estratégias individuais. Instituto de Pesquisa Jardim Botânico do Rio de Janeiro, Rio de Janeiro. 84p.

Willison J, Kneebone S \& Bromley G (2006) Implementing Target 14 of the Global Strategy for Plant Conservation: An International Review. Retrieved from London, UK.

Wyse-Jackson P \& Kennedy K (2009) The global strategy for plant conservation: a challenge and opportunity for the international community. Trends in plant Science 14: 578-580. 